\title{
Action as a Missing Link Between the Concepts and Practice of Geography Teaching
}

\author{
Clemens Wieser
}

\begin{abstract}
Teaching geography involves a teacher who takes actions in respect to subject matter. While such actions are performed everyday, analysing teaching action is not a trivial matter. Teaching depends on the subject matter taught, resulting in teaching actions specific to subjects. To analyse how action is conceptualised for geography education, the paper reviews four research approaches prominent in German-speaking geography education and highlights how action is conceptualised in concepts for geography teaching. The review analyses conceptualisations of action in research on (1) student interests in geography, (2) everyday life concepts of students, (3) conceptual change, and (4) Educational Reconstruction. Analysis shows that current research on geography education aims to suggest strategies for teaching, but does not conceptualise teaching and learning as interaction between teachers and learners. Analysis is followed by an outline posing a contribution to the empirical analysis of teaching actions and classroom interaction in geography education.
\end{abstract}

Key words: geography teachers, geographical education, classroom interaction, secondary school education

\section{Akcija kao karika koja nedostaje između ideje i prakse u geografskom poučavanju}

Poučavanje geografije uključuje profesora koji poduzima razne akcije povezane s nastavnim sadržajem. Iako se takve akcije poduzimaju svakodnevno, analiza akcija učenja ne može se smatrati trivijalnom. Poučavanje ovisi o nastavnom sadržaju i rezultira akcijama specifičnim za svaki predmet. U svrhu analize koncepata akcije u geografskom obrazovanju, u ovom radu analiziraju se četiri istaknuta pristupa istraživanju u geografskom obrazovanju na njemačkom jeziku i naglašava se kako je akcija zamišljena u strategijama geografskog poučavanja. U članku se analizira konceptualizacija istraživačkih aktivnosti u (1) učeničkom zanimanju za geografiju (2) svakodnevnom životu učenika (3) konceptualnim promjenama i (4) rekonstrukciji obrazovanja. Analiza je pokazala da trenutni radovi na temu geografskog poučavanja sugeriraju strategije poučavanja, ali ne koncipiraju poučavanje i učenje kao interakciju između učitelja i učenika. Uz analizu je dan i doprinos empirijskoj analizi akcija u poučavanju geografije i interakcije u razredu.

Ključne riječi: profesori geografije, nastava geografije, interakcija razreda, srednjoškolsko obrazovanje 


\section{INTRODUCTION}

Teacher training in geography demands that it be practical. It has to be practical because future teachers expect their training to support their own teaching. One way of providing such support is to develop concepts for teaching geography with regard to classroom interaction, which can be split up into teacher actions and student actions. Support has increasingly been provided by concepts developed through empirical research on geography teaching. In German-speaking countries, empirical research saw a tremendous boost in the 1980s, succeeding a tradition of non-empirical concepts developed in the tradition of philosophy of education. Even though concepts were developed through empirical research, those concepts were not necessarily practical. For geography teachers, a concept becomes practical when teaching becomes easier for him/her. Research on actions in geography classes hence can be highlighted as a way to scaffold geography teaching. Consequently, research on geography education has to develop concepts that take actions in geography teaching into account. Concepts grounded in analysis of both teacher and student actions are able to give account to the complexity of teaching in schools. Such concepts are capable of providing support for teachers and scaffold their action because they comprehend the challenges of everyday teaching.

\section{CONCEPTUALISATIONS OF ACTION IN RESEARCH ON GEOGRAPHY EDUCATION}

Since existing concepts for teaching geography aim to be practical, it can be assumed that they take action into account. The following analysis reviews conceptualisations of action in research on (1) student interests in geography, (2) everyday life concepts of students, (3) conceptual change, and (4) Educational Reconstruction.

\section{Research on student interests in Geography and how to include student interests in Geography teaching}

One large-scale research project on student interests in geography has been conducted by Hemmer et al (2005). The survey was part of an interdisciplinary project hosted at the Leibniz Institute for Science Education (Leibniz-Institut für die Pädagogik der Naturwissenschaften, IPN). Besides the main survey, the project encompassed a series of smaller studies to analyse student concepts and learning difficulties and develop teaching materials. The main survey of the project aimed to identify student interests in geo sciences, learning activities through which students want to work on these topics and contexts in which geo science topics become relevant to students. The conceptual background for the survey was informed by interest theories developed in educational psychology. The survey was motivated by the idea that student interest is required to initiate learning and that situated interest might develop when students are provided with attractive subject matters and learning environments. A questionnaire developed was split into three parts (cf. Hemmer et al. 2007, 188): the first part evaluated the attractiveness of eleven geo science topics (e.g. 'rocks and minerals', 'fossil resources', 'gas hydrates') in specific learning activities and contexts (e.g. societal, systemic, spatial context). The second part surveyed topics and contexts separately, while the third part examined self-contained exploration 
of geo-science topics outside of school. The survey was conducted using a quantitative approach, which resulted in operationalising topics and contexts in closed questions and standardised items. The third part of the questionnaire included one open question. Figure 1 displays a questionnaire section of topic-context-combination items. Abbreviations in the left column represent specific topics ( $\mathrm{G}$ for 'Gegenstand', in this case 'rocks and minerals') und specific contects ( $\mathrm{K}$ for 'Kontext').

\begin{tabular}{|c|c|c|c|c|c|c|}
\hline \multicolumn{2}{|r|}{ My Interest to find out more about ...... is } & \multirow{2}{*}{$\begin{array}{r}\text { very } \\
\text { high }\end{array}$} & \multirow{2}{*}{$\begin{array}{l}\text { high } \\
\square\end{array}$} & \multirow{2}{*}{\begin{tabular}{|c|} 
average \\
$\square$ \\
\end{tabular}} & \multirow{2}{*}{ small } & \multirow{2}{*}{\begin{tabular}{|r|}
$\begin{array}{r}\text { very } \\
\text { small }\end{array}$ \\
$\square$ \\
\end{tabular}} \\
\hline G3K1 & $\begin{array}{l}\text {... types of rock that can be found in } \\
\text { my hometown }\end{array}$ & & & & & \\
\hline G3K2 & $\begin{array}{l}\text {... precious stones and their relevance } \\
\text { for economy }\end{array}$ & $\square$ & $\square$ & $\square$ & $\square$ & $\square$ \\
\hline G3K3 & $\begin{array}{l}\text {... whether mining projects should be } \\
\text { allowed in places where rare species of } \\
\text { plants grow }\end{array}$ & $\square$ & $\square$ & $\square$ & $\square$ & $\square$ \\
\hline $\mathrm{G} 3 \mathrm{~K} 4$ & $\begin{array}{l}\text {... how rock formation is influenced } \\
\text { by climate, organisms and processes } \\
\text { within the structure of the earth }\end{array}$ & $\square$ & $\square$ & $\square$ & $\square$ & $\square$ \\
\hline G3K5 & $\begin{array}{l}\ldots \text { how deep rocks were buried } \\
\text { before they reached the surface of the } \\
\text { earth today. }\end{array}$ & $\square$ & $\square$ & $\square$ & $\square$ & $\square$ \\
\hline G3K6 & $\begin{array}{l}\ldots \text { why it is possible to find rocks } \\
\text { that are millions of years old in Africa }\end{array}$ & $\square$ & $\square$ & $\square$ & $\square$ & $\square$ \\
\hline G3K 7 & $\begin{array}{l}\ldots \text { which types of rock the Alps are } \\
\text { made of }\end{array}$ & $\square$ & $\square$ & $\square$ & $\square$ & $\square$ \\
\hline G3K8 & $\begin{array}{l}\ldots \text { how rocks can be determined } \\
\text { using a microscope }\end{array}$ & $\square$ & $\square$ & $\square$ & $\square$ & $\square$ \\
\hline
\end{tabular}

Fig. 1 Questionnaire section on topic-context-combinations (Source: Hemmer et al. 2005, 61; translated) Sl. 1. Dio upitnika s kombinacijama tema i sadržaja (Izvor: Hemmer i sur., 2005:61, prijevod autora)

Research findings indicated that "interest shown by students (...) was generally of medium intensity, independently of the topic-context combination" and that "no genderrelated differences were found" (Hemmer et al 2007, 189). Analysis of contexts showed that "all respondents showed high interest" in contexts "individual/personal concern", "societal relevance", and "social responsibility". Preferred student learning activities identified were hands-on activities such as "guided tours through a research institute", "visits to exhibitions" and "running their own experiments". The final discussion of findings highlights that topics relevant to everyday life and environmental protection are most interesting to students.

The value of the study lies in identifying student interest in topics of geography and geo sciences and contexts that additionally foster interest of students. "This being so, teachers may crucially influence their students' interest by their selection and legitimation of a topic as well as by integrating it in a suitable context" (Hemmer et al. 2007, 193). The findings allow teachers to prepare lessons with respect to topics that are generally 
interesting for students and to contextualise topics in a way that makes the topic interesting for their audience. Hemmer et al. $(2007,193)$ add: "As a general rule, interest is encouraged by linking a subject to the students' everyday experiences out of school, and/ or by establishing a traceable connection to the realities of their lives." This rule of thumb however raises a problem: How teachers impart knowledge to their students, e.g., by spontaneously taking up a context that is communicated as relevant by students in a specific class, cannot be answered by the survey discussed here. How teachers teach - how they prepare a topic for teaching, e.g., choose a specific geographic representation in respect to a complex phenomenon, impart their knowledge to students - does not get into focus. Leaving teaching action out of research has been identified as a problem, since " general goals of much fundamental learning research do not mesh well with the operating logic of current schools" (Rothkopf 2008, 352).

Teachers are confronted on an everyday basis with interpreting student actions and with an array of tasks unrelated to subject knowledge. They have to deal with student interest when they start teaching, beyond generally knowing what might be of interest for students in general. For a teacher, student interests become evident while interacting with students. Student interest is perceived through actions of students, expressing attentiveness or boredom while the teacher attempts to impart knowledge. Such expressions can be understood by close observation, consequently allowing for the reconstruction of phenomena like boredom "as a signifier of the individual's retreat out of the situation" (Breidenstein 2007). Student interests become manifest through actions in a social space (Leander 2002), where learning preferences might seem paradox (Beach 2008). Findings like these mentioned here indicate that analysing phenomena allows insights into teaching and learning actions. The student interest survey conducted by Hemmer et al. $(2005 ; 2007)$ itself points to the necessity of taking student and teacher actions into account. Hemmer et al. $(2007,192)$ discovered that "young people hardly occupy themselves at all with the topics under discussion during their leisure hours", leading to little to no knowledge on geo science topics. This discovery strikingly points to the distance of student interests and topics dealt with in geography lessons. In consequence, geography education needs to develop strategies to make teachers capable of understanding student interests and their perspectives and give voice to them in the classroom. This has been underlined by another study on student interest, pointing out that "the interrelationships between teacher interest, pupil interest and curriculum content need further investigation" (Trend 2007, 170).

\section{Understanding everyday life concepts for teaching geography}

The importance of giving voice to student interests and their perspectives is emphasised in research on everyday life concepts' of students related to geography. In a study on student concepts, Schuler $(2009,2)$ argues that the success of concepts for teaching geography is largely dependent on the integration of everyday life concepts of students. The idea underpinning the study is that everyday life concepts are relevant for learning since learning alters or expands everyday life concepts. Schuler looks at student concepts of threats and vulnerability caused by global climate change. Schuler interviewed students and asked how they evaluate the impact of climate change on human life in Africa and Germany. He also asked students to draw conceptual maps in order to visualise their 
concepts. The findings discussed report a clear contrast between evaluations of threat and vulnerability (Fig. 2): Students perceive climate change to have a stronger impact on human life in Africa (upper bar in Fig. 2) than in Germany (central bar) or in their own lives (lower bar).

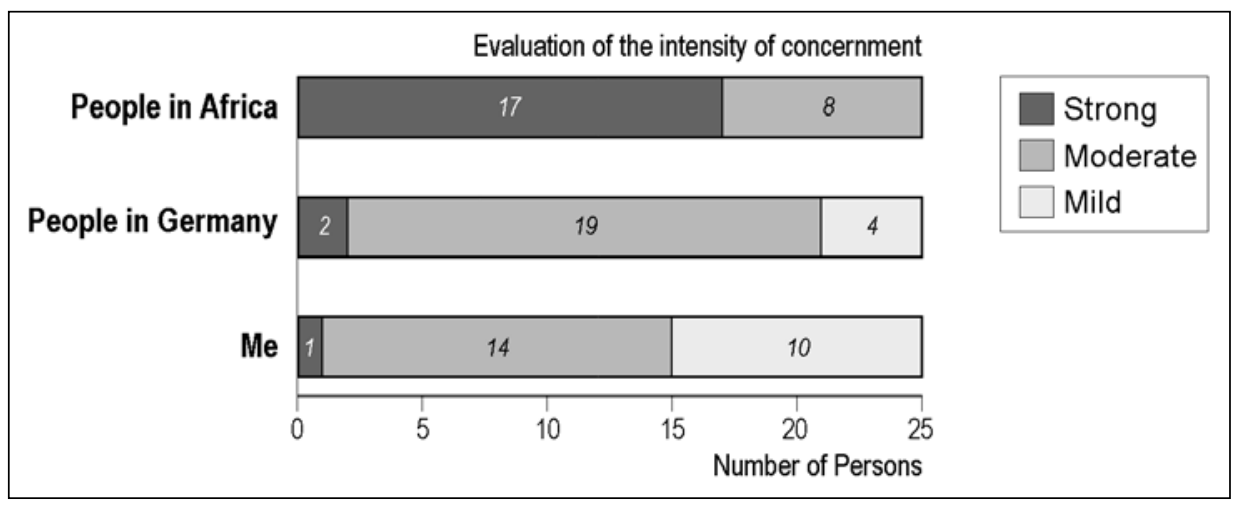

Fig. 2 Impact of climate change on human life in Africa and Germany as perceived by German secondary school students (Source: Schuler 2009, 11; translated)

Sl. 2. Percepcija klimatskih promjena i njihov utjecaj na život u Africi i Njemačkoj učenika njemačkih srednjih škola

To change the evaluations of students, Schuler sees little use in labelling the everyday life concepts of students as incorrect, since they are the starting point of learning. This argument leads to an urging question for geography education: How can everyday life concepts of students be made into starting points of learning in the classroom? Schuler $(2009,25)$ states that concepts for teaching should incorporate two major steps: firstly, students should become aware of their concepts and make their everyday life concept explicit; and, secondly, students should confront their view with an expert view independently und widely uncontrolled. Teaching strategies that include these two steps are judged to be reliable in taking everyday life concepts of students into account.

How are these two steps realised in geography teaching? Teachers are asked to develop teaching in two phases. However, the proposition does not cover how teachers can practically access students' concepts. This missing coverage can be unsettling when teachers are confronted with students who do not show interest in comparing their concept with an expert concept. Other research on everyday life concepts of students reveals similar problems: Wustmann and Schleicher (2009) studied everyday life concepts of primary school students regarding the glacial lake development. Wustmann and Schleicher (2009, 94) argue that using regional examples helps students to tie up everyday life knowledge and geography topics, thus employing Lake Constance as a local example to discuss glacial lake development in their study. The study concludes that teachers should use regional examples when discussing abstract topics in class. Similar to the study of Hemmer et al $(2005$; 2007) discussed first, this proposition tacitly assumes that teachers will be able 
to access everyday life concepts of students and know how to support their students in elaborating their concept by taking appropriate actions.

\section{Conceptual change and interpretation of student actions}

Everyday life concepts are key in conceptual change research on geography education. However, the idea underpinning conceptual change research differs. The difference becomes evident when looking at conceptual change studies. Conceptual change happens when students change their subjective concept - of, e.g., the Greenhouse Effect (Reinfried et al. 2010), karst formation (Ritter and Reinfried 2008), glacier movement (Reinfried and Hug 2008), or meteorite impacts (Müller 2007) - to a more tenable concept. The idea underpinning conceptual change research is that teaching should result in students changing their subjective concepts. Since conceptual change happens subjectively, it cannot directly be accessed through teaching. Reinfried $(2009,2)$ analyses beliefs embedded in subjective concepts, since overcoming those beliefs are the major difficulty in performing conceptual change: "Re-learning in the sense of conceptual change can happen when a new concept induces a cognitive conflict in the learner". This is why Reinfried $(2009,3)$ suggests constructivist learning environments to support conceptual change. "Results imply that (...) instructional constructivist settings (...) are better suited to laying the foundation for understanding complex and abstract environmental problems" compared to conventional teaching material. This result was found through a pretest-posttest design and with two testbeds - one using conventional teaching material, the other one constructivist teaching material - comparing the learning efficacy of both settings. Taking the conceptual change study on glacier movement as an example, the survey showed that students are practically unaware of differences between glaciers and icebergs. Since the subjective concepts were indifferent in respect to the phenomena under discussion in class, students had difficulties to understand the concept of glacier movement. Such findings from conceptual change research allow explaining how subjective concepts of geographic entities can change and what obstacles students have to overcome in performing conceptual change.

Facilitating conceptual change in real-life classroom environments, however, still proves to be difficult. Reinfried and Hug $(2008,42)$ suggest teaching definitions of icebergs and glaciers to highlight the differences between the two. To make subjective concepts explicit, a mental modelling strategy is suggested in order to stimulate seeing and interpreting differences. However, how this strategy is enacted is not in the focus of empirical research. Consequently, teacher actions that $d o$ stimulate change and student actions that show how such teacher actions are taken up are out of focus. Conceptual change as a learning psychology model is capable of illustrating cognitive processes. In respect to action, however, such models do not take into account teacher actions aimed to facilitate conceptual change (Hackl 2007, 79). Reinfried $(2007,26)$ is widely aware of that problem. She states that subjective concepts and scientific concepts normally converge through actions and interaction: until research findings on classroom interaction are presented, teachers have no choice but to observe their students and see how they get along in learning. The strategy of mental modelling can be understood as an educational counterpart to the psychological model of conceptual change. Nevertheless, the strategy for educational practice stays prescriptive. The sequence of actions in the classroom is 
not part of empirical investigation, thus not revealing what a teacher does when enabling students to perform conceptual change.

\section{Educational Reconstruction and teacher action}

Similar to the strategy of mental modelling, Educational Reconstruction aims to facilitate teacher action based on empirical research. Educational Reconstruction was established by a group of German science education researchers (Kattmann et al. 1997). The aim is to enable teachers to plan lessons based on findings from Educational Reconstruction. Lesson planning should be based on fundamental and reliable findings using educational goals, contents and methods validated by Educational Reconstruction. Educational Reconstruction interrelates three research areas to achieve this goal (Fig. 3):

- Scientific clarification: Analysis of the structure of a particular content clarifies scientific concepts, their function and the area of their application. For this clarification process, a content analysis approach is used (Gropengießer 2006). Scientific publications, textbooks, essays or expert reports act as a data base for analysis. The analysis results in clarifying key concepts developed in respect to a specific subject matter.

- Empirical investigation of students 'concepts: The goal of the investigation is to analyse student concepts in respect to (1) entities in which the subject matter is perceived, (2) subjective explanations on the qualities of the subject matter, and (3) the experiences that led to the subjective concept (relating to research on everyday life concepts). Student concepts are usually examined using interviews and learning experiments.

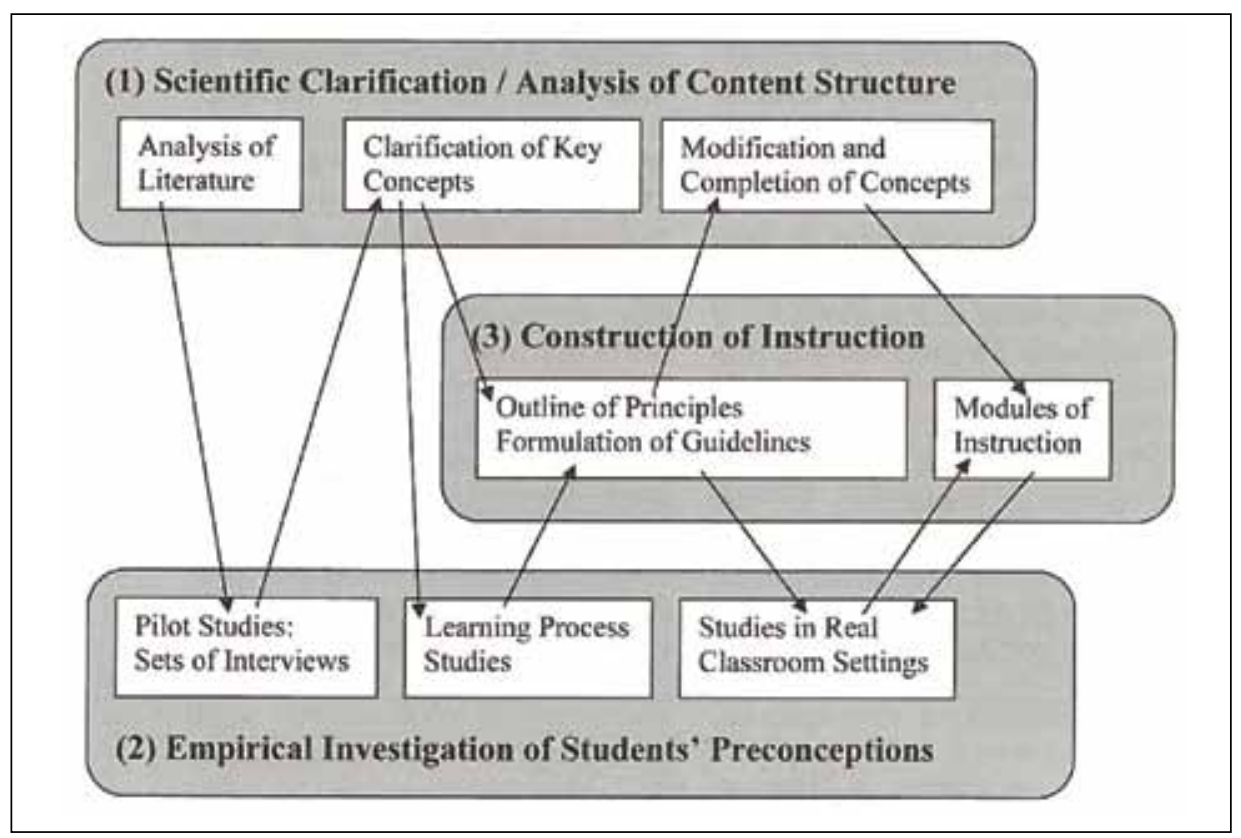

Fig. 3 The process of Educational Reconstruction (Source: Komorek et al. 2003)

Sl. 3. Proces rekonstrukcije obrazovanja (Izvor: Komorek i sur., 2003). 
- Construction of instruction: Based on scientific clarification and investigated student concepts, modules of instruction, material and tasks are developed. The instructional design is developed drawing from constructivist learning theories and theories on concept development and conceptual change. In respect to conceptual change, Educational Reconstruction researchers stress that everyday life concepts must not be treated as misconceptions (Kattmann 2007, 98).

Educational Reconstruction allows systematically designing instruction that accounts for differences between scientific and everyday life concepts. How a teacher instructs following instruction designs developed through Educational Reconstruction, how he/ she presents the subject matter, and how students endorse presentation and instructional offer does not get reconstructed by Educational Reconstruction - a problem shared with other research approaches such as student interest research. Respectively, it remains unclear if and how the subject matter became relevant for students or whether the teacher was successfully acting as an agent between subject matter and learner, hence imparting knowledge on the subject matter to students. The development of instructional material in which the subject matter is reified is based on systematic analysis. However, the context of learning in compulsory schooling remains widely ignored. Similar to the research approaches discussed earlier, actions and interaction in real-life classrooms are not taken into account. Like other research approaches, Educational Reconstruction remains prescriptive in respect to teaching and learning interactions. Educational Reconstruction allows developing an instructional design, but does not conceptualise instruction as acts of teaching, or respectively as interaction of teachers and learners.

\section{CONCEPTUALISING ACTION FOR RESEARCH ON GEOGRAPHY TEACHING}

The research approaches in geography education discussed here are remarkable in that all of them aim to suggest strategies for teaching, but do not analyse teaching and learning as interaction between teachers and learners. In all cases, the concepts for teaching geography remain prescriptive - what should happen in class is specified without analysing interaction in class. However, the research approaches discussed show a tendency of aligning closer to teaching action than previous approaches. Even though research on classroom actions and interaction has been identified as relevant to geography education (Kanwischer 2008,113), empirical work in geography education is still pending. To propel such empirical work, this paper will conclude in three steps, outlining (1) an epistemological framework of actors and entities of learning and teaching interaction, (2) methodological challenges in surveying and analysing such interaction, and (3) conceptual foundations of analysing learning and teaching interaction. These perspectives have been gathered from systems theory, ethnography and reconstructive educational research. They are currently employed to reconstruct practices of imparting and acquiring knowledge in geography classes (Wieser 2010).

\section{Actors and entities of learning and teaching interaction}

The discussion of research approaches in geography education showed that little research has been conducted on teaching and learning as interaction. Teaching action 
usually remained a matter corresponding with research, but hardly ever became the very focus of it. Student interest research identified which topics are generally most interesting for students, though surveys never focussed on teachers and students interacting in geography education research to date. Research on everyday life concepts comprehended what students have in mind when thinking about phenomena related to geography. The step-by-step guidelines developed allowed bringing up scientific concepts in respect to everyday life concepts. However, how a teacher in class does perform those steps has not been investigated - neither in research on everyday life concepts nor in conceptual change research on geography education. Consequently, learning and teaching interaction has to get into focus. In secondary schools, teaching and learning take place in class, giving respective actions a specific context. Specifics of classroom interaction are that teaching actions see a specific time horizon. Teaching and learning are interrupted by the rhythm of school classes (usually about an hour), continuously disrupting interaction and reconvening teaching and learning in respect to a subject matter. Other specifics of school culture like assessment add further qualities to the roles of students and teachers. Gruschka $(2002,121)$ developed an epistemological framework for research on secondary school teaching and learning, identifying actors of learning and teaching interaction and entities those actors deal with. This epistemological framework has been specified to fit research on geography education (Fig. 4).

Actors are split up in two groups, teachers and students. Both deal with specific material representations (teaching material) of phenomena of reality. Phenomena related to geography - e.g., spatial demographic or economic developments - are usually not at hand in class due to their complex and indiscernible nature. ${ }^{2}$ They are discussed in class

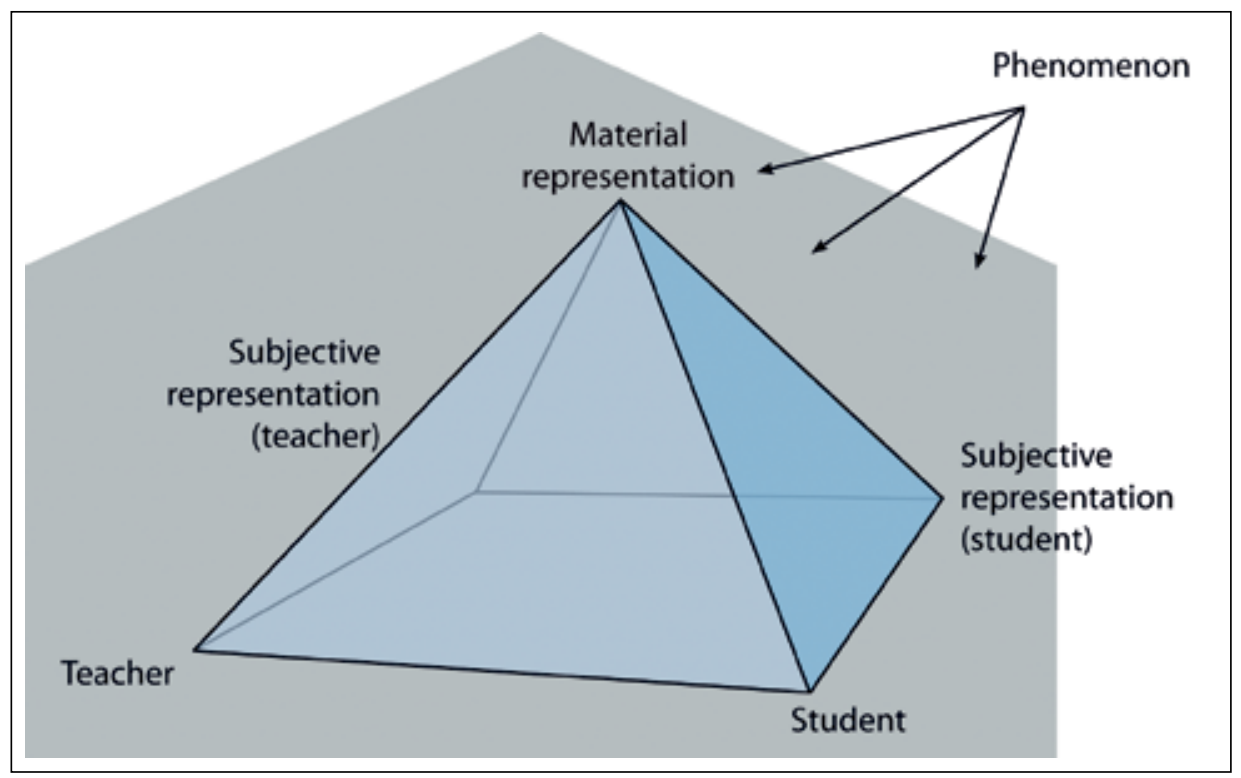

Fig.4 Actors and entities of learning and teaching

Sl. 4. Činitelji i entiteti učenja i poučavanja 
using material representations. Students learn by drawing upon their everyday life concept of the phenomenon (e.g., knowledge acquired through media consumption) and by dealing with the material representation presented to them by the teacher (Wieser 2008). While traditional signifiers like "content" or "topic" usually blur the specifics of entities of learning and teaching, this framework allows addressing the signified entities more accurately. The framework for research on geography education proposed here discerns between the phenomenon itself, scientific representations of that phenomenon intersubjectively developed in geography, subjective representations of students originating in their everyday life experience, and material representations contained in teaching materials such as schoolbooks. Geography teachers use these material representations to operate as agents between students and the phenomenon, acting as negotiators of knowledge in the structural context of school.

\section{Methodological challenges in surveying and analysing classroom interaction}

Starting from this conceptual framework, methods of surveying action in the classroom have to be identified. Educational researchers have highlighted the necessity of developing a phenomenology of actions of learning and teaching (Reusser 2008, 224; Blömeke and Müller 2008, 241-243) and qualitative surveying to avoid reification processes that would take place through operationalisation: "Analytic science has proven itself a powerful means to understand those phenomena that are relatively stable (...). However, analytic science has been almost useless for making sense of those phenomena that can transform themselves (...) such as societal norms or personal understandings" (Jörg et al. 2007,149150). Another common methodological point of critique is that experimental research cannot reflect characteristics of classroom actions. Reusser $(2008,232)$ conceptualises teacher actions as facilitating for learning actions, stating that teaching should cultivate learning processes. This conceptualisation renders teaching and learning a social process that happens besides cognitive processes. Such social processes are calling for qualitative surveying strategies like audio and video recording of classroom interaction. Transcribed recordings allow for qualitative interpretations of interaction. Methodological tools currently in use for interpretative analysis are Educational Ethnography (Walford 2008), Grounded Theory Methodology (Glaser and Strauss 1965; Corbin and Strauss 2008) or Objective Hermeneutics (Bohnsack 2010; Wernet 2006).

\section{Conceptual foundations of analysing learning and teaching interaction}

To further facilitate analysis, fundamental qualities of classroom interaction can be described conceptually. One fundamental conceptualisation of social interaction has been developed by Luhmann and Schorr (1982) and has been presented as the concept of double contingency. Since classroom interaction is one specific case of social interaction, the concept can facilitate analysis. Double contingency denotes that every action is based on the interpretation of previous actions. Every interpretation of previous action is contingent, which means that the interpretation is not necessarily valid, but seems adequate and reasonable for the interpreter. Since both teachers and students interpret actions, contingency is inherent in classroom interaction. The social context of classroom interaction provides 
specific challenges for coping with uncertainty that lies in double contingency. One challenge is that classroom settings scarcely allow students to make explicit their understanding of a subject matter A teacher who would allow students to do so would inevitably stretch interaction over the available time horizon. Double contingency allows revealing another challenge of teaching and learning interaction: Since interpretations are contingent, it becomes impossible to assume aims of teaching set by teachers are equivalent to aims of learning set by students. Practically, the aims of the teacher become comprehensible to students by the actions of the teacher - for example, by presenting learning objectives. Concurrently, those objectives are aims that the teacher obliges students to fulfil, thus making their learning non-autonomous and thereby potentially constraining students' learning.

\section{CONCLUSION: POTENTIALS OF RESEARCH ON ACTION IN GEOGRAPHY EDUCATION}

The epistemological, methodological and conceptual frameworks presented in this paper provide strategies specifically adapted for surveying and analysing geography education. These strategies allow surveying and analysing classroom interaction as it takes place, thus reducing distance from practices of teaching and learning geography than research approaches discussed in the first section of this paper. The distance between research and pedagogical practice can be traced back to the problems of the German "Didaktik" tradition, which has poorly reflected the complexity of teaching and learning interaction over recent decades (Scheunpflug 2000, 5). Similar arguments for taking complexity into account have been recently made in international research not aligned with the German "Didaktik" tradition. Mainzer $(2004,407)$ argues that "linear thinking may be dangerous in a non-linear complex reality". Morin $(2001,70)$ states that educational research must approach such complex reality cautiously, "understanding the uncertainty of reality, knowing that the real holds invisible potential". Jörg et al. $(2007,154)$ conclude that a new "complexity paradigm" for doing research on learning and teaching such as action research will not "provide access to an ultimate truth; it is, rather, that such a paradigm seems to be better fitted to out rapidly evolving, ever-more-complicated times".

Research on geography education that looks at learning and teaching actions allows interpreting what students and teachers do while dealing with subject matters related to geography. Such research is specific to geography education since it focuses on ways in which knowledge is imparted by teachers and acquired by students in geography. Teaching and learning always relate to a phenomenon (Terhart 2002, 83), while impartment and acquisition of knowledge mimetically resemble that phenomenon. This mimetic resemblance also shows in scientific disciplines like geography that deal with specific groups of phenomena and explore them. Giving an example, phenomena of complex social reality are represented through subjects of social geography. How knowledge is acquired and imparted in social geography classes is currently being investigated by recording classroom interaction, doing teacher interviews - before lessons concerning preparation and lesson plan, after lessons to explore perceptions of events in class - and student interviews to comprehend how they perceived the lesson, how the topic became relevant to them and how they acquired knowledge through class (Wieser 2010). 
Research on geography education that draws on the outlined frameworks and strategies can lead to understanding (1) how teachers impart geographic knowledge to students, (2) how students acquire subjects of geography, and (3) how educational aims are worked out in geography teaching. Early case study analysis shows that teachers use the classroom to elicit and negotiate concepts of geography with students. Negotiation is often initiated through a discussion of everyday representations of the phenomenon in the first lesson of a course series on a specific topic in geography classes. One possibility of doing so is to discuss knowledge presented in media, assuming that students developed their everyday concepts from knowledge presented there. Through discussion, representations in the media are evaluated. Evaluation penetrates the closedness of the representation in the media, thus challenging the students' subjective concepts. By challenging their own concepts, students might experience a personal crisis in understanding the phenomenon. This crisis can be overcome by acquiring new knowledge. How subject- specific knowledge is imparted and acquired can only be understood by conducting subject-specific educational research. This argument is backed up by early findings in learning psychology (Nussbaum 1979; Vosniadou 1994).

Case studies analysis can provide teachers with systematic interpretations of processes of teaching and learning social geography. Case studies can act as a fundament for reflecting on teacher and student actions in the classroom. Through case studies, teachers can learn about practices of teaching and learning in their subject, which can support them in plotting their own teaching actions as well as in interpreting students' learning actions. Learning to systematically interpret teaching and learning actions can furthermore lead to sensitivity towards phenomena that are likely to appear while teaching, thus scaffolding professional action. By acquiring strategies for interpreting classroom interaction, teachers can develop routines that they can use heuristically while acting in class. Such heuristics allow for situational interpretations of ongoing classroom events, which can be used by teachers to guide further actions and enact teaching as being an agent between subject matter and learner.

\section{REFERENCES}

Beach, D., 2008: The paradoxes of student learning preferences, Ethnography and Education, 3:2, 145-159.

Blömeke, S., Müller, Ch., 2008: Zum Zusammenhang von Allgemeiner Didaktik und Lehr-Lernforschung im Unterrichtsgeschehen, Zeitschrift für Erziehungswissenschaft, Special Edition 10:9, 239-258.

Bohnsack, R., 2010: Rekonstruktive Sozialforschung. Einführung in qualitative Methoden, Opladen.

Breidenstein, G., 2007: The meaning of boredom in school lessons. Participant observation in the seventh and eighth form, Ethnography and Education, 2:1, 93-108.

Corbin, J., Strauss, A., 2008: Basics of Qualitative Research, Thousand Oaks.

Glaser, B., Strauss, A., 1965: The Discovery of Grounded Theory. Strategies for Qualitative Research, New York. Gropengießer, H., 2006: Lebenswelten, Denkwelten, Sprechwelten, Oldenburg.

Gruschka, A., 2002: Didaktik. Das Kreuz mit der Vermittlung. Elf Einsprüche gegen den didaktischen Betrieb, Wetzlar. 
Hackl, B., 2007: Abschied von der Vermittlung? Zeitgeistige Didaktiken als Konzepte sinnreduzierter Wirklichkeitserschließung, in: Hackl, B.; Pechar, H. (eds.): Bildungspolitische Aufklärung. Um- und Irrwege der österreichischen Schulreform, Innsbruck, 71-86.

Hemmer, I., Hemmer, M., Bayrhuber, H., Häußler, P., Hlawatsch, S., Hoffmann, L., Raffelsiefer, M., 2005: Interesse von Schülerinnen und Schülern an geowissenschaftlichen Themen. Ergebnisse einer Interessenstudie im Rahmen des Projekts „Forschungsdialog System Erde” unter besonderer Berücksichtung des Geographieunterrichts, Geographie und ihre Didaktik, 2005:2, 57-72.

Hemmer, I., Bayrhuber, H., Häußler, P., Hemmer, M., Hlawatsch, S., Hoffmann, L., Raffelsiefer, M., 2007: Students' interest in geoscience topics, contexts and methods, Geographie und ihre Didaktik, 2007:4, 185-197.

Husserl, E., 1954: Die Krisis der europäischen Wissenschaften und die transzendentale Phänomenologie, Dordrecht

Jörg, T., Davis, B., Nickmans, G., 2007: Towards a new, complexity science of learning and education, Educational Research Review, 2007:2, 145-156.

Kanwischer, D., 2008: Schwachstelle Lehrerbildung: empirische Befunde zum Fach- und Lehrverständnis Thüringer Geographielehrer, Geographie und ihre Didaktik, 2008:3, 97-114.

Kattmann, U., Duit, R., Gropengießer, H., Komorek, M., 1997: Das Modell der Didaktischen Rekonstruktion. Ein theoretischer Rahmen für naturwissenschaftsdidaktische Forschung und Entwicklung, Zeitschrift für Didaktik der Naturwissenschaften 1997:3, 3-18.

Kattmann, U., 2007: Didaktische Rekonstruktion - eine praktische Theorie, in: Krüger, D., Vogt, H., (eds.): Theorien in der biologiedidaktischen Forschung, Berlin, 93-104.

Komorek, M., Stavrou, D., Duit, R., 2003: Nonlinear physics in Upper Physics Classes. Educational Reconstruction as a Frame for Development and Research in a Study of Teaching and Learning Basic Ideas of Nonlinearity, in: Psillos, D., Kariotoglou, P., Tselfes, V., Hatzikraniotis, E., Fassoulopoulos, G., Kallery, M. (eds.): Science Education in the Knowledge-Based Society, Dordrecht, 309-322.

Leander, K. M., 2002: Silencing in Classroom Interaction: Producing and Relating Social Spaces, Discourse Processes, 34:2, 193-235.

Luhmann, N., Schorr, K.-E., 2000: Problems of reflection in the system of education, Münster.

Mainzer, K., 2004: Thinking in complexity. The computational dynamics of matter, mind, and mankind, Berlin.

Morin, E., 2001: Seven complex lessons in education for the future, Paris.

Müller, M., 2007: Students' concepts about meteorite impacts on earth-geographical assessment and pedagogical consequences, Geographie und ihre Didaktik, 2007:4, 218-232.

Nussbaum, J., 1979: Children's conceptions of the earth as a cosmic body: A cross age study, Science Education, 1979:60, 535-550.

Reinfried, S., 2007: Alltagsvorstellungen und Lernen im Fach Geographie. Zur Bedeutung der konstruktivistischen Lehr-Lern-Theorie am Beispiel des Conceptual Chance, Geographie und Schule 168, 19-28.

Reinfried, S., Hug, F., 2008: Von Eisklumpen, Eismeeren und Strömen aus Eis. Gletscherbewegungen sichtbar machen und Schülervorstellungen verändern, Geographie Heute 265, 40-47.

Reinfried, S., 2009: Examining Conceptual Change on the Greenhouse Effect and Global Warming using cognitive conflict strategy in a constructivist learning environment, in: Çakmakci, G., Tasar, M. F. (eds.): Contemporary Science Education Research: Learning and Assessment. Proceedings of the European Science Education Research Association ESERA 2009 Conference, Istanbul, 129-133.

Reinfried, S., Rottermann, B., Aeschbacher, U., Huber, E., 2010: Wirksamkeit einer lernpsychologisch optimierten Lernumgebung auf die Veränderungen von Schülervorstellungen über den Treibhauseffekt und die globale Erwärmung - eine Pilotstudie, Geographie und ihre Didaktik, 2010:4, 205-226.

Ritter, M., Reinfried, S., 2008: Wie entsteht eine Karstlandschaft? Schülervorstellungen von Dolinen weiterentwickeln, Geographie Heute 265/266, 14-19. 
Rothkopf, E., 2008: Reflections on the Field: Aspirations of Learning Science and the Practical Logic of Instructional Enterprises, Educational Psychology Review, 2008:20, 351-368.

Reusser, K., 2008: Empirisch fundierte Didaktik - didaktisch fundierte Unterrichtsforschung. Eine Perspektive zur Neuorientierung der Allgemeinen Didaktik, Zeitschrift für Erziehungswissenschaft, Special Edition $10: 9,219-237$.

Scheunpflug, A., 2000: Didaktische Theoriebildung. Ein kritischer Aufriss ihrer handlungstheoretischen Logik, Hamburg.

Schuler, S., 2009: Schülervorstellungen zu Bedrohung und Verwundbarkeit durch den globalen Klimawandel, Geographie und ihre Didaktik, 2009:1, 1-28.

Schütz, A., 1973: The structures of the life-world, Evanston.

Terhart, E., 2002: Fremde Schwestern. Zum Verhältnis von Allgemeiner Didaktik und empirischer Lehr-LernForschung, Zeitschrift für Pädagogische Psychologie, 16(2), 77-86.

Trend, R., 2007: Fostering progress in children's developing geoscience interests, Geographie und ihre Didaktik, 2007:4, 168-184.

Vosniadou, S., 1994: Capturing and Modeling the Process of Conceptual Change, Conceptual Change, Learning and Instruction, Special Issue 4, http://www.cs.phs.uoa.gr/en/staff/32.\%20vosniadou\%201994.pdf (29.12.2010), 45-69.

Walford, G., 2008: How to do Educational Ethnography, Oxford.

Wernet, A., 2006: Einführung in die objektive Hermeneutik, Wiesbaden.

Wieser, C., 2008: Beziehungen zwischen Lebenswelt und Lernen. Eine Untersuchung zu Semantik, Verwendung und Problemen einer zentralen Denkfigur der Geographiedidaktik, in: Dobler, K., Jekel, T., Pichler, H. (eds.): kind : macht : raum, Heidelberg, 134-153.

Wieser, C., 2010: Wie Geographie und Wirtschaftskunde vermittelt und angeeignet wird. Geographie aktuell, IV:2010, 6 .

Wustmann, K., Schleicher, Y., 2009: Möglichkeiten empirischer Unterrichtsforschung in der Lehramtsausbildung. Das Beispiel geographischer Alltagsvorstellungen von Grundschulkindern zur Entstehung des Bodensees, Geographie und ihre Didaktik, 2009:2, 80-96.

Received (Primljeno): 2010 - $12-30$

Accepted (Prihvaćeno): $2011-05-20$

\section{Clemens Wieser}

Department of Geography and Regional Research

University of Vienna, Austria

clemens.wieser@univie.ac.at 